\title{
Characteristics of Land Market in Nigeria: Case of Ibeju Lekki Local Government, Lagos, Nigeria
}

\author{
Victoria 0. Odunfa ${ }^{*}$, A. O. Agboola ${ }^{2}$, T. T. Oladokun ${ }^{2}$ \\ ${ }^{1}$ Department of Estate Management and Valuation, The Polytechnic, Ibadan, Nigeria \\ ${ }^{2}$ Department of Estate Management, Obafemi Awolowo University, Ile-Ife, Nigeria \\ Email: *Odunfavictoria@gmail.com
}

How to cite this paper: Odunfa, V. O., Agboola, A. O., \& Oladokun, T. T. (2021). Characteristics of Land Market in Nigeria: Case of Ibeju Lekki Local Government, Lagos, Nigeria. Current Urban Studies, 9, 1-16. https://doi.org/10.4236/cus.2021.91001

Received: January 1, 2020

Accepted: January 15, 2021

Published: January 18, 2021

Copyright () 2021 by author(s) and Scientific Research Publishing Inc. This work is licensed under the Creative Commons Attribution International License (CC BY 4.0).

http://creativecommons.org/licenses/by/4.0/

(c) (i) Open Access

\begin{abstract}
This study examined the characteristics of land market in Ibeju Lekki Lagos, Nigeria with a view to enhancing the operation of the land market. Data were collected through the administration of questionnaire on residents of Ibeju Lekki, key developers in the area and Land Bureau officials. Pilot survey revealed that there were 81 communities in the study area. Ten (10\%) percent of the 81 communities were purposively selected representing 9 communities with 3155 housing units. Systematic sampling technique with a random start was used to select one of every sixteenth landholder giving 203 housing units. Total enumeration of all the identified 9 indigenous landowners was interviewed and 7 officials of Bureau of Lands in Lagos State were sampled for questionnaire administration. Data collected were analysed using residents' perception index, mean deviation, factor analysis and regression analyses respectively. The results showed that the prominent characteristics of the land market in the area with their corresponding mean values were: easy transaction in the market (2.69), improved environmental management (2.49), easy accessibility to market (2.41), good lending conditions (2.35), efficient land use management (2.34), Certainty of land ownership (2.3), land regulation (2.14) and access to experts (2.04). Using factor analysis, the study established that equity, accessibility and finance explained $12.77 \%, 12.64 \%$ and $9.09 \%$ of the total variance. The study thus established the land market characteristics which could have positive significant effects on the operation of the land market; in the study area.
\end{abstract}

\section{Keywords}

Characteristics, Land Market, Omo-onile, Enhancement, Environmental Management 


\section{Introduction}

Urban centres of developing and developed nations are faced with myriads of land-related problems which include land accessibility variations (Oloyede, Ajibola, \& Oni, 2007), differences in cultural norms and customs of the society, legal framework, regulations, conventions and institutions (North, 2009) among others. The magnitude of these problems and the solutions that have been proffered differ across world economies. While advanced countries have been able to manage these problems to a considerable extent, the problem is on daily increase in developing countries (Oloyede et al., 2007). Nevertheless, land market has received a considerable amount of attention globally with land preponderantly regarded as the center of all human activities (Annette, 2002), necessitating the need for easy access to land, especially in developing countries like Nigeria. Efficient and effective land market is a tool for effective development. With Land serving as a platform for every other form of development, city growth might be largely influenced by the structure and characteristics of the land market (Nwaka, 2005). Land market is driven mostly by institutions, which serve to regulate its operations and the activities of the various operators. While formal institutions are duly regulated and operated by government policies, law and regulations, informal/institutions are the results of the beliefs, practices and customs of the local people as to the way and manner by which land should and could be held in society. It is a long-time practice of land holding, ownership and transfer popularly adopted within a society (Funmilayo et al., 2015).

As a system for the exchange of rights and interest in land, the market is important for the success of every other component of the economy as all activities take place on land. It is a major factor for consideration for sustaining the growth of emerging economies' (Oladokun, 2017). However, the efficient functioning of the market can be affected by its characteristics. Whether for transacting in both rental and sales market, it is of interest to know whether the system is structured for both formal or informal market. Even where both are encouraged, the modus operandi of the market players (whether individuals, firms or government) stand the possibility of making or marring the efficiency of a market. It could either discourage or encourage investment in the market in the cities/urban centres.

African urban land market seems to be gaining the attention of international communities. As an emerging, Nigeria, for instance is becoming a preferred place for foreign investors. Lagos, a former capital of Nigeria, adjudged to be a mega city seems to be considered a viable option for land investors. It is believed among practitioners that Lagos offers the most active land market in Nigeria and by extension in Africa. If the city will accommodate the growing rising population of about 22 million on a land area of the characteristics of the land must be such that is adequate and sufficient to meet the perceived growing demand of the population (Holden, 2013). Land institutions must be strong end dynamic to meet the yearnings of international and foreign investors who are encouraged by 
the privatisation policies of the Nigerian government, especially as it affects Nigerian major cities like Lagos.

The city of Lagos seems to be undergoing the development of informal sector activities via Omo-onile in land acquisition with the fear of chocking up the formal sector. This development is attributable to the failure of the formal institutions to deliver adequate land to would-be users which pave way for informal rules (Rakodi \& Leduka, 2003). This development is encouraged by the fact that a larger percentage of the populace in low-income level could not afford the high formal land sale prices; the development that metamorphosed into increased patronage of the informal market. It is believed that there is high preponderant of the influence of the informal institutions and proliferation of Omo-onile (also known as traditional landowners) on the land market of Nigeria and Lagos in particular (Adeniyi, 2013). With the influence of Lagos mega city on the larger African economy, the study seeks to investigate the characteristics of the land market. The finding will provide sufficient information for both local and foreign individuals as well as institutional developers for effective land decision making.

\section{Literature Review}

\section{Land Market and Characteristics}

Generally, the literature divides land market into two basic areas. First, are those that viewed informal land market as emanating from the concept of capitalist market, in which case the activities of agents in land market is connected with the general framework of the process of acquisition. The second view is that the cost associated with illegality explains informal land market.

A general understanding of urban land market in Africa was defined by Kironde (2000) as a "framework in which those seeking land own or control land for land acquisition are treated by land seekers" and in which the market framework is determined by the definition of the participants in it and their rationalities. It is the institution concerned with the transfer of ownership rights on land (Emmanuel, 2008) and a major factor for consideration for sustaining the growth of emerging economies (Oladokun, 2017). If viewed in terms of agent categories vis-à-vis developers, investors and users, Mooya and Cloete (2007) classified land market into 'development markets, capital markets and letting markets.

Land markets are prohibited in some countries as such leading to landlessness and concentration of land in fewer hands (Siastad, 2003). In most African countries, however, formal and informal land market transactions operating at both rental and sales sectors are allowed. Whereas, the informal land sales market develops where land is scarce and the distribution of land and land factors is distorted incentive for market transaction in land (Hodson, 2000), the formal land system was imposed primarily by colonial powers. For instance in Nigeria, the 
feudal power structure in 1975 where colonial powers alienated local population in various ways taking them as tenants on crown land which attracts payment of taxes or labor extraction. The colonial masters took charge of greater percentage of land in Lagos and the practice entail the exchange of land created by the practice as a major policy issue. Access to land has been unequal from time immemorial and has become more unequal in recent decades (Jayne \& Keller, 2003).

There was general recognition in South East, Asia that the informal (illegal) market is the main way the people access land. The same opinion was given by Calderon (1996), for Latin American cities by the 1990s. Rakodi and Leduka (2003) also discovered the same fact for six cities in Sub-Saharan Africa and Emmanuel (2008) corroborated this fact also in Kampala Uganda. The submissions of authors such as: Angel et al. (1983) in South East Asia, Calderon (1999) in Latin America and Rakodi (2006), also give corroboration to the fact that the informal land market are the most common way by which people access land. In all ways, land market process starts with allocation of land to ensure balancing between the quality of land supplied and quantity demanded and ensuring the efficient use of land (Deininger et al., 2011).

Four advantages of efficient equitable land market as opined by Baland (2007) are as follows; when the value of land use rights is capitalized in any forecast mortgage or land price estimate, transaction costs in the market for buying and selling land tend to be higher, with associated fixed costs, at registration may be higher and household smaller and smaller. Poor households will have more difficulty obtaining land, as serious gaps in the credit and insurance markets, and repeated negative shocks will force young landowners selling even bigger hardships, while (usually wealthy landowner) able to secure or diversify its operations and in the absence or when the capital market is accessible to a large number of the population, land ownership is used to accumulate savings, especially as inflation hedging, which costs less levels of efficient productive use.

What differentiates urban land market in Africa is that they are independent of public authorities (Kironde, 2000). This form of land market is unique from other markets where it would be buyer(s) trades and no proper knowledge of land market is possible without grasp of its characteristics (Ajayi, 1998). The land market is significant in its level of imperfections.

Factors that have contributed to the imperfection include the following; First, there is no central market place or quoted current price. Land sale can take place through various sub-markets according to purpose, location and type. The fact that there is no quoted price will make the seller (valuer) conduct investigation on relevant recent sales. Second, there is inadequate knowledge on transaction due to lack of fixity of market place and great deals of secrecy accompany transactions in land market. Third, supply of land is fixed in nature which lead to monopoly of the product by the seller. Fourth, transaction in land market can be complex via finance and legal arrangement. Finally, the market is surrounded by various interests (Dowall, 1993; Greenspan, 1994). 


\section{Research Method}

The study concentrated on Lagos mega city, which is adjudged as the commercial nerve centre of the most populous African city called Nigeria. The Lagos land market is adjudged to be one of the most vibrant land market in the country.

The study population for this study consisted of indigenous landholders, residents, property developers and top officials of Bureau of Lands in Lagos state. This population groups were sampled because of their active involvement in land market activities. The Local government area studied comprised eighty-one communities namely Abijo, Awoyaya, Eputu, Lakowe, Bogije, Sapeti/lgando-Oloja, Ibeju Lekki, Arapagi, Oke-odo Elemoro, Akodo, Magbon, Alade, Eleko, Debojo, Solu-Alade, lwerekun, Mapo, Ajiran and others. The information that is peculiar to the study was extracted from selected individual land owners and community heads within Ibeju Lekki communities and this was effected through physical contact with the stakeholders.

The study focused on indigenous landholders, residents, developers and top officials of Land Bureau in Lagos who have been observed to be active actors in land market. Pilot survey revealed that there were 81 communities in the study area from where nine (9) communities were selected randomly. In order to ensure adequate representation of the population and obtain comprehensive data for the study. The total number of housing units in each of the nine selected communities was ascertained through the local government and chairmen of the residents association thus: Abijo 418, Iba onigangan-181, Elebutu-452, Ibeju-356, Waterside-231, Solu Alade-397, Debojo-246, Eputu-440 and Adeba-434. The information obtained showed that altogether, there were 3,155 housing units within the nine randomly selected communities. Hence, the sampling frame for the study is nine indigenous landholders, five developers. Seven (7) officials of Land Bureau and two hundred and three residents (landholders) who are stakeholders in Lagos land market.

Multi stage sampling techniques adopted for the study consisted of the purposive as well as the systematic sampling techniques. Ten (10) percent of the 81 communities in Ibeju Lekki were purposively selected. Afterwards, In selecting the residents (landholders), systematic sampling technique was used to select one of every sixteen (16) (representing 6.5\% of the sampling frame) building after the first house has been randomly selected representing a total of 203 housing units. A resident (landholder) was thereafter selected for questionnaire administration in each of the 203 selected buildings. In addition, (5 key developers) representing $6 \%$ of the 87 developers registered with Real Estate Developers Association of Nigeria (REDAN) Lagos branch, was sampled. Also, a total enumeration of all the identified 9 indigenous landholder/heads of the selected communities was interviewed and questionnaire administered on 7 officials (departmental heads) of Bureau of Lands in Lagos state to buttress the information retrieved from landholders. Data collected were analysed with descriptive and inferential statistic of resident perception index factor analyses and regres- 
sion analysis

Descriptive Analysis of the Characteristics of Land Market in the Study Area

The identified characteristics of land market were analysed using Mean Index (MI). A total of 23 land market characteristics were identified to determine the Mean Index (MI) in order to determine the level of importance attached to each characteristic so as to be able to know which of the variables are most important and least important as the case may be. In order to calculate MI, respondents are advised to assess each characteristic using one of five assessments. Strongly Agree-5, Agree-4, Fairly Agree-3, Disagree-2 and Strongly Disagree-1. The summations of the weight value (SWV) were obtained for each indicator by adding the response product to each variable class and the respective weight values. Mathematically, it is portrayed as:

$$
\mathrm{SWV}=\sum_{i=1}^{5} x_{i} y_{i}
$$

where: SWV = Summation of Weight value;

$X_{i}=$ number of respondents to rating $i$;

$y_{i}=$ the weight assigned to a value $(i=1,2,3,4,5)$.

The MI for each indicator is arrived at by dividing the summation of weight value by the addition of the number of respondents to each of the five ratings. This is expressed mathematically as:

$$
\mathrm{MI}=\frac{\mathrm{SWV}}{\sum_{i=1}^{5} P_{i}}
$$

where RII is the relative importance index, SWV and $P_{i}$ are defined previously. The closer the RII of a particular indicator to 5 , the higher is assured of the level of importance attached to such purpose.

Findings as presented in Table 1 established importance attached to the land market characteristic by the respondents. The characteristic that have the highest ranking is easy transaction in the market $(\mathrm{MI}=2.69)$, while the least characteristic is suitable use for investor $(\mathrm{MI}=1.35)$. In order of importance, the characteristics that were rated highly are: Easy transaction in the market $(M I=2.69)$, Improved environmental management $(\mathrm{MI}=2.46)$, Easy Accessibility to the market $(\mathrm{MI}=2.41)$, Good condition by lender $(\mathrm{MI}=2.35)$, efficient land use management $(\mathrm{MI}=2.34)$, and certainty of land ownership $(\mathrm{MI}=2.30)$. The land market characteristics that have moderate ranking are as follows: Land regulation $(M I=2.14)$ and Access to experts $(M I=2.04)$. while all others were rated low, they are: Presence of formal structure $(M I=1.87)$, Use availability of credit $(M I=1.78)$, Safety of market participants $(M I=1.77)$, Presence of indigenous land owner $(\mathrm{MI}=1.70)$, Use of land as collateral $(\mathrm{MI}=1.65)$, Efficiency $(\mathrm{MI}=$ 1.63), Enhanced information flow $(\mathrm{MI}=1.55)$, Regulation on land admin $(\mathrm{MI}=$ $1.55)$, Secured title/tenure to land $(\mathrm{MI}=1.54)$, Guaranteed equal right $(\mathrm{MI}=$ $1.52)$, Equity $(\mathrm{MI}=1.46)$, Presence of mortgage assets $((\mathrm{MI}=1.45)$, Quick 
Table 1. Descriptive analysis of the characteristics of land market in the study area.

\begin{tabular}{|c|c|c|c|c|c|c|c|c|c|c|c|c|c|}
\hline \multirow{3}{*}{ Indicators } & \multicolumn{10}{|c|}{ Level of Agreement } & \multirow{3}{*}{ swV } & \multirow{3}{*}{ MI } & \multirow{3}{*}{$\mathbf{R}$} \\
\hline & \multicolumn{2}{|c|}{ SD (1) } & \multicolumn{2}{|c|}{$\mathrm{D}(2)$} & \multicolumn{2}{|c|}{ FA (3) } & \multicolumn{2}{|c|}{ A (4) } & \multicolumn{2}{|c|}{ SA (5) } & & & \\
\hline & $\mathbf{F}$ & $\%$ & $\mathrm{~F}$ & $\%$ & $\mathrm{~F}$ & $\%$ & $\mathbf{F}$ & $\%$ & $\mathbf{F}$ & $\%$ & & & \\
\hline Easy transaction in market & 54 & 27.6 & 39 & 19.9 & 48 & 24.5 & 24 & 12.2 & 31 & 15.2 & 527 & 2.69 & $1^{\text {st }}$ \\
\hline Improved environmental Mgt & 91 & 46.4 & 17 & 8.7 & 34 & 17.3 & 14 & 7.1 & 40 & 20.4 & 483 & 2.46 & $2^{\text {nd }}$ \\
\hline Easy accessibility to market & 78 & 39.8 & 35 & 17.9 & 32 & 16.3 & 27 & 13.8 & 24 & 12.2 & 472 & 2.41 & $3^{\text {rd }}$ \\
\hline Good condition by lenders & 89 & 45.4 & 10 & 5.1 & 46 & 23.5 & 41 & 20.9 & 10 & 5.1 & 461 & 2.35 & $4^{\text {th }}$ \\
\hline Efficient land use management & 88 & 44.9 & 25 & 12.8 & 38 & 19.4 & 19 & 9.7 & 26 & 13.3 & 458 & 2.34 & $5^{\text {th }}$ \\
\hline Certainty of land ownership & 96 & 49.0 & 21 & 10.7 & 24 & 12.2 & 35 & 17.9 & 20 & 10.2 & 450 & 2.30 & $6^{\text {th }}$ \\
\hline Land regulation & 101 & 51.5 & 24 & 12.2 & 27 & 13.8 & 30 & 15.3 & 14 & 7.1 & 420 & 2.14 & $7^{\text {th }}$ \\
\hline Access to experts & 120 & 61.2 & 8 & 4.1 & 23 & 11.7 & 31 & 15.8 & 14 & 7.1 & 399 & 2.04 & $8^{\text {th }}$ \\
\hline Presence of formal structure & 124 & 63.3 & 17 & 8.7 & 23 & 11.7 & 20 & 10.2 & 12 & 6.1 & 367 & 1.87 & $9^{\text {th }}$ \\
\hline Availability of credit & 124 & 63.3 & 31 & 15.8 & 12 & 6.1 & 19 & 9.7 & 10 & 5.1 & 348 & 1.78 & $10^{\text {th }}$ \\
\hline Safety of market participants & 133 & 67.9 & 14 & 7.1 & 17 & 8.7 & 25 & 12.8 & 7 & 3.6 & 347 & 1.77 & $11^{\text {th }}$ \\
\hline Presence of indigenous owner & 134 & 62.4 & 24 & 12.2 & 10 & 5.1 & 19 & 9.7 & 9 & 4.6 & 333 & 1.70 & $12^{\text {th }}$ \\
\hline Use of land as collateral & 139 & 70.9 & 24 & 12.2 & 13 & 6.6 & 2 & 1.0 & 18 & 9.2 & 324 & 1.65 & $13^{\text {th }}$ \\
\hline Efficient & 132 & 67.3 & 38 & 19.4 & 6 & 3.1 & 7 & 3.6 & 13 & 6.6 & 319 & 1.63 & $14^{\text {th }}$ \\
\hline Enhanced information flow & 149 & 76.0 & 13 & 6.6 & 16 & 8.2 & 10 & 5.1 & 8 & 4.1 & 303 & 1.55 & $15^{\text {th }}$ \\
\hline Regulation on land admin. & 147 & 75.0 & 17 & 8.7 & 17 & 8.7 & 4 & 2.0 & 11 & 5.6 & 303 & 1.55 & $16^{\text {th }}$ \\
\hline Secured title/tenure to land & 149 & 76.0 & 19 & 9.7 & 12 & 6.1 & 2 & 1.0 & 14 & 7.1 & 301 & 1.54 & $17^{\text {th }}$ \\
\hline Guaranteed equal right & 136 & 69.4 & 32 & 16.3 & 18 & 9.2 & 6 & 3.1 & 4 & 2.0 & 298 & 1.52 & $18^{\text {th }}$ \\
\hline Equitable & 140 & 71.4 & 40 & 20.4 & 5 & 2.6 & 3 & 1.5 & 8 & 4.1 & 287 & 1.46 & $19^{\text {th }}$ \\
\hline Presence of mortgage assets & 150 & 76.5 & 20 & 10.2 & 15 & 7.7 & 5 & 2.6 & 6 & 3.1 & 285 & 1.45 & $20^{\text {th }}$ \\
\hline Quick development & 149 & 76.0 & 29 & 14.2 & 4 & 2.0 & 6 & 3.1 & 8 & 4.1 & 283 & 1.44 & $21^{\text {st }}$ \\
\hline land as collateral & 158 & 80.6 & 11 & 5.6 & 19 & 9.7 & 3 & 1.5 & 5 & 2.6 & 274 & 1.40 & $22^{\text {nd }}$ \\
\hline Sustainable use for investor & 149 & 76.0 & 36 & 18.4 & 5 & 2.6 & 1 & 0.5 & 5 & 2.6 & 265 & 1.35 & $23^{\text {rd }}$ \\
\hline
\end{tabular}

Source: Author's Field Survey (2019).

development $(\mathrm{MI}=1.44)$, land as collateral $(\mathrm{MI}=1.40)$ and Sustainable use for investor $(\mathrm{MI}=1.35)$.

Invariably, the prominent characteristics of the land market in the study area as rated by the respondents are easy transaction in market, Improved environmental Management, Easy access to market, Good condition by lenders, Efficient land use mgt., Certainty of land ownership, Land regulation, Lack of access to experts. The remaining land market characteristics exist but were not prominent in the study area. Further analysis is then being carried out to actually group the characteristics according to their prominence in the study area using factor analysis. The factor analysis was employed to reduce the 23 identified land 
market characteristics to specific harmonious components.

\section{Characteristics of Land Market by Factor Analysis}

The Kaiser Mayer Olkin (KMO) was measured on the appropriateness of sampling and Bartlett's test of spherical testing to test the suitability of the dataset for factor analysis. 23 variables were loaded for analysis of factors and the result was shown to be adequate, as shown in Table 2. The KMO value of K70 0.707 exceeding the minimum of 0.5 , Bartlett's test of the value of a spherical square of 1510.162 and great value of $0.000(p \leq 0.05)$ in agreement with the Field (2007) and the Agbabiaka (2016). Therefore, analysis of factors analysis is considered relevant and possible for this study.

Furthermore, Table 3 presents the initial communalities of the factors before extraction though principal component analysis is with an initial assumption that all variables are common with 1.000 each. After extraction, it was observed that each variable reflects common variance in the data set, which is evident in the proportion of the variance explained by the underlying factors. For instance, safety of participants in the market (0.801), improved environmental management (0.773), sustainable use of investor (0.739), enhanced free flow of information (0.736) and efficient land use management (0.733) have high associated variation. Other variable with lower associated variation are guaranteed equal right (0.543), easy accessibility to market (0.575), secured title/tenure to land (0.577), lack of access to expert (0.606) and favourable conditions by lenders (0.621). It is estimated that the extracted community must be high for rational expression. The average community calculated in Table 3 is 0.679 (67.9\%), which is important for the analysis of key partners.

Findings as presented in Table 4, the rotated component matrix revealed the type of variable loaded highly on each factor. Factor 1 accounted for $12.77 \%$ variance, factor 2 accounted for $12.64 \%$ variance, factor 3 accounted for $9.09 \%$ variance, factor 4 accounted for $7.42 \%$, factor 5 accounted for $6.64 \%$ variance and factors 6 and 7 accounted for $6.56 \%$ and $6.44 \%$ variance respectively, while factor 8 accounted $7.38 \%$ variance of the total variance explained. This study will be interpreted in line with 41 Agbabiaka (2016) who adopted 0.55 and above, therefore, variables loaded with value that is greater than or equal to 0.55 were considered significant and included in the interpretation. Accordingly, component 1 has four variables loaded highly on it, such as: efficiency (0.757), quick development (0.741), equitable (0.644) and guaranteed equal right (0.608). This

Table 2. KMO and Bartlett's test.

\begin{tabular}{ccc}
\hline Kaiser-Meyer-Olkin Measure of Sampling Adequacy & & 0.707 \\
Bartlett's test of Sphericity & Approx. Chi-square & 1510.168 \\
& Df & 253 \\
& Sig & 0.000 \\
\hline
\end{tabular}

Source: Author’s Field Survey (2019) 
Table 3. Communalities before and after extraction process.

\begin{tabular}{lll}
\hline & Initial & Extraction \\
\hline Efficiency & 1.000 & 0.665 \\
Quick development & 1.000 & 0.701 \\
Equitable & 1.000 & 0.660 \\
Sustainable use for investor & 1.000 & $0.739 t$ \\
Easy accessibility to market & 1.000 & 0.575 \\
Easy transaction in market & 1.000 & 0.645 \\
Use availability of credit & 1.000 & 0.707 \\
Use of land as collateral & 1.000 & 0.708 \\
Presence of local owner & 1.000 & 0.661 \\
Presence of mortgage assets & 1.000 & 0.659 \\
Acceptance of land as collateral & 1.000 & 0.695 \\
Favorable condition by lenders for granting loan & 1.000 & 0.621 \\
Lack of access to experts & 1.000 & 0.606 \\
Presence of formal structure & 1.000 & 0.733 \\
Secured title/tenure to land & 1.000 & 0.577 \\
Improved environmental Mgt & 1.000 & 0.773 \\
Efficient land use management & 1.000 & 0.733 \\
Enhanced free flow of information & 1.000 & 0.736 \\
Guaranteed equal right & 1.000 & 0.543 \\
Safety of participant in the market & 1.000 & 0.801 \\
Certainty of ownership of land & 1.000 & 0.707 \\
Land regulation by tenure & 1.000 & 0.691 \\
Land regulation by land administration system & 1.000 & 0.683 \\
\hline
\end{tabular}

Source: Author's Field Survey (2019).

Table 4. Rotated component matrix.

\begin{tabular}{lcccccccc}
\hline \multicolumn{1}{c}{ Factors } & \multicolumn{7}{c}{ Component } \\
\cline { 2 - 8 } & $\mathbf{1}$ & $\mathbf{2}$ & $\mathbf{3}$ & $\mathbf{4}$ & $\mathbf{5}$ & $\mathbf{6}$ & $\mathbf{7}$ & $\mathbf{8}$ \\
\hline Efficiency & 0.757 & -0.007 & 0.026 & -0.052 & 0.016 & -0.084 & -0.276 & 0.067 \\
Quick development & 0.741 & -0.057 & -0.030 & -0.095 & 0.047 & 0.348 & -0.020 & 0.126 \\
Equity & 0.644 & -0.188 & 0.011 & -0.237 & 0.029 & 0.349 & -0.072 & 0.160 \\
Sustainable use for investor & 0.106 & -0.090 & 0.110 & -0.070 & 0.097 & 0.833 & 0.001 & 0.022 \\
Easy access to market & -0.158 & 0.244 & -0.068 & -0.124 & -0.117 & -0.041 & 0.674 & 0.025 \\
Easy transaction in market & -0.206 & 0.591 & -0.319 & 0.131 & -0.333 & -0.105 & -0.106 & -0.019 \\
Availability of credit & -0.057 & -0.132 & 0.035 & 0.794 & 0.072 & -0.185 & -0.071 & 0.104 \\
Use of land as collateral & 0.180 & -0.118 & 0.590 & 0.311 & 0.038 & 0.098 & 0.384 & 0.242 \\
\hline
\end{tabular}




\section{Continued}

\begin{tabular}{lcccccccc}
\hline Presence of indigenous owner & 0.517 & -0.165 & 0.485 & -0.002 & 0.075 & 0.100 & 0.336 & -0.046 \\
Presence of mortgage assets & 0.043 & -0.141 & 0.788 & -0.047 & 0.104 & -0.008 & 0.030 & 0.049 \\
Acceptance of land as collateral & -0.036 & 0.134 & 0.738 & 0.096 & 0.071 & 0.115 & -0.282 & 0.155 \\
Good condition to lenders & -0.064 & 0.584 & 0.035 & 0.003 & -0.073 & -0.115 & 0.506 & -0.026 \\
Access to experts & -0.130 & -0.340 & 0.143 & 0.518 & 0.223 & 0.347 & 0.044 & 0.112 \\
Presence of formal structure & 0.551 & -0.219 & -0.072 & 0.365 & 0.459 & 0.034 & 0.175 & -0.026 \\
Secured title/tenure to land & 0.043 & -0.036 & 0.105 & 0.220 & 0.260 & 0.161 & 0.415 & 0.499 \\
Improved environmental Mgt & -0.186 & 0.718 & -0.158 & -0.320 & -0.078 & -0.214 & 0.169 & 0.123 \\
Efficient land use management & -0.284 & 0.701 & 0.067 & -0.046 & 0.026 & 0.193 & 0.145 & -0.308 \\
Free flow of information & 0.331 & 0.002 & 0.033 & 0.412 & -0.295 & 0.432 & -0.216 & -0.367 \\
Guaranteed equal right & 0.608 & -0.175 & 0.217 & 0.223 & -0.049 & -0.196 & 0.060 & -0.045 \\
Safety of market participant & 0.145 & 0.007 & 0.205 & 0.047 & -0.172 & -0.017 & -0.037 & 0.839 \\
Certainty of ownership of land & -0.033 & 0.781 & -0.040 & -0.223 & 0.184 & -0.071 & 0.038 & 0.072 \\
Land regulation by tenure & -0.009 & 0.011 & 0.137 & 0.060 & 0.802 & 0.060 & -0.101 & -0.103 \\
Land regulation byland admin & 0.266 & 0.447 & 0.206 & 0.183 & 0.474 & 0.089 & -0.113 & 0.301 \\
Eigenvalue & 2.936 & 2.906 & 2.090 & 1.706 & 1.527 & 1.508 & 1.481 & 1.466 \\
\% variance explained & 12.77 & 12.64 & 9.09 & 7.42 & 6.64 & 6.56 & 6.44 & 6.38 \\
Cumulative \% & 12.77 & 25.40 & 34.49 & 41.91 & 42.54 & 55.10 & 61.54 & 67.91 \\
\hline
\end{tabular}

Source: Author's Field Survey (2019).

factor is named Equity factor based on the nature of the variables loaded highly on it.

Component 2 has five variables loaded highly on it, they are: easy transaction in the market (0.591), good conditions by lenders for granting loans (0.584), improved environmental management (0.718), efficient Land use management (0.701) and certainty of ownership (0.781). These variables are referred to as Accessibility factor.

Component 3 has three variables loaded highly, they are: Land use as collateral (0.590), presence of mortgage assets (0.788) and acceptance of land as collateral (0.738). This variable is referred to as Finance factor.

Component 4, 5, 6, 7 and 8 had none or only one variable each loaded highly on them and has been disregarded as stipulated by Field (2007).

The summary of the variance explained by the extracted components after rotation is presented in Table 5. Findings revealed that equity factor is an important categorization of land market characteristics in the study area as they accounted for $12.77 \%$ among the rest of factors extracted. Equity shows that there is fairness in the market, if a participant in the land market follows the laid down procedure and deals with established stakeholders in the market, such individual's interest in the market will be secured and guaranteed from all encumbrances. This shows that equitable interest exists in the market. The next component in the 
Table 5. Summary of characteristics of land market.

\begin{tabular}{cccc}
\hline Factors & Eigen value & \% of Variance & Cumulative \% \\
\hline Equity & 2.936 & 12.77 & 12.77 \\
Accessibility & 2.906 & 12.64 & 25.40 \\
Finance & 2.090 & 9.09 & 34.49 \\
\hline
\end{tabular}

Source: Author's Field Survey (2019).

order of loading variability among the 23 variables is Accessibility factor with $12.64 \%$ of the extracted component.

Little or no specialized knowledge is needed when entering into the land market, the market is fairly accessible for all interested stakeholders according to the respondents. This shows that the market does not need specialized knowledge and does not require the services of a third party before a person can achieve his aim in the market. The accessibility characteristic adds to the robustness of the land market and allows for more participants to participate in the buying, leasing and selling of land. The last component which is finance factor with a variance of $9.09 \%$ of the extracted components is an important categorization. In land acquisition, finance is very crucial, without the ability to back up one's needs with financial resources demand will not be effective. The Ibeju-Lekki sub-division of Lagos is one of the fastest developing areas of the State. The presence of the Free Trade Zone (FTZ), proposed deep sea port and many other commercial and industrial establishments has led to a rapid increase in the value of land in the area, with prices very competitive and on an upward trajectory. Invariably, the three factors accounted for $34.49 \%$ variation, meaning that 12 out of the 23 variables employed as indicator were loaded highly and were categorized and named accordingly as characteristics of land market. This confirmed the work of Oloyede, Osmond and Ayedun (2011) who stated the loaded factors as characteristics of land market in their study on informal land market an alternative approach to mass residential housing provision in South-Western Nigeria. This infers that the importance of equity accessibility and finance factors cannot be over emphasized for an effective operation of the market.

Descriptive Analysis of the Perceived Effect of Omo-onile Activities on the Characteristics of Land Market in the Study Area

Prolonged transaction time is one of the perceived effects of the Omo-onile activities on land market characteristics in the study area. Findings established as presented in Table 6 revealed majority 166 (84.7\%) of the respondents attest to the fact that Omo-onile activities always delay the time of transaction on land in the land market. Personal discussion with some of the respondents and interview conducted with the selected community heads during the survey periods revealed that whenever any member of the Omo-onile by chance have an information that a particular piece of land is for sale, they will go and place a caution on the land so that any prospective buyer will be scared away and the owner will 
Table 6. Descriptive analysis of the effect of Omo-onile activities on land market characteristics.

\begin{tabular}{|c|c|c|c|c|c|c|c|c|c|c|c|c|}
\hline \multirow{3}{*}{ Indicators } & \multicolumn{10}{|c|}{ Level of Agreement } & \multirow{2}{*}{\multicolumn{2}{|c|}{ Total }} \\
\hline & \multicolumn{2}{|c|}{$\mathrm{SD}(1)$} & \multicolumn{2}{|c|}{$\mathrm{D}(2)$} & \multicolumn{2}{|c|}{$\mathrm{N}(3)$} & \multicolumn{2}{|c|}{ A (4) } & \multicolumn{2}{|c|}{ SA (5) } & & \\
\hline & $\mathbf{F}$ & $\%$ & F & $\%$ & F & $\%$ & F & $\%$ & F & $\%$ & F & $\%$ \\
\hline Prolonged transaction time & 3 & 1.5 & 0 & 0.0 & 1 & 0.5 & 26 & 13.3 & 166 & 84.7 & 196 & 100 \\
\hline Increase in transaction cost & 2 & 1.0 & 0 & 0.0 & 2 & 1.0 & 34 & 17.3 & 158 & 80.6 & 196 & 100 \\
\hline Fraudulent/multiple sales & 2 & 1.0 & 3 & 1.5 & 7 & 3.6 & 135 & 68.9 & 49 & 25.0 & 196 & 100 \\
\hline Frequency of violence & 1 & 0.5 & 0 & 0.0 & 5 & 2.5 & 38 & 19.4 & 152 & 77.6 & 196 & 100 \\
\hline frequency of litigation & 0 & 0.0 & 0 & 0.0 & 3 & 1.5 & 41 & 20.9 & 152 & 77.6 & 196 & 100 \\
\hline Frequency of conflict & 0 & 0.0 & 2 & 1.0 & 0 & 0.0 & 38 & 19.4 & 155 & 79.1 & 196 & 100 \\
\hline Tenure insecurity & 0 & 0.0 & 0 & 0.0 & 1 & 0.5 & 31 & 15.8 & 64 & 83.7 & 196 & 100 \\
\hline Prolonged completion period & 0 & 0.0 & 0 & 0.0 & 4 & 2.0 & 57 & 29.1 & 135 & 68.8 & 196 & 100 \\
\hline Project abandonment & 0 & 0.0 & 4 & 2.0 & 2 & 1.0 & 85 & 43.4 & 105 & 53.6 & 196 & 100 \\
\hline
\end{tabular}

Source: Author's Field Survey (2019).

be forced to go and make negotiation with them. By this act, they prolong the transaction time in the land market. Majority $158(80.6 \%)$ of the respondents attest to the assertion that the activities of Omo-onile always increase transaction cost. This was further deduced from the contact with the respondents who express with bitterness that the Omo-onile force the owners of properties to enter into an agreement with them and as such the owner will add the extra cost on the coated price for the sales of the land, which invariably has increased the supposed price of the land. Fraudulent and multiple sales of land is another effect that emanates from the activities of Omo-onile in the study area. Findings revealed that $135(68.9 \%)$ of the respondents agrees with the assertion that the activities of Omo-onile are fraudulent in the sense that they sell land that do not belong to them to more than one person, causing chaos and litigation on land. Findings revealed that the effect of Omo-onile activities on land market characteristics in the study area are violence (152 (77.6\%)), Frequency of litigation (152 (77.6\%)), frequency of conflict (155 (79.1)), tenure insecurity (164 (83.7\%)) prolonged completion period $(135(68.8 \%))$ and project abandonment (105 $(53.6 \%))$. All these effects were attested to by majority of the respondents, the respondents expressed their dissatisfaction toward the various activities of Omo-onile in the environment, but there is nothing they can do about it. Some of the respondents assert that the activities of the Omo-onile are uncivilized, uncultured and recalcitrant.

Regression Analysis on the Effect of Omo-onile Activities on Land Market Characteristics.

Multiple regression analysis was used to analyze the loaded factors that categorized the land market characteristics in order to access the effect of Omo-onile activities on it. For this study three factors were derived and were subjected to 
multiple regression analysis in order to identify the degree of the effect of Omo-onile activities on them Findings as presented in Table 7 and Table 8 revealed that the multiple regression model in which the three predictors produced $\left(\mathrm{R}^{2}=0.105, \mathrm{~F}=6.365, \mathrm{p} \leq 0.000^{\mathrm{a}}\right)$. The regression $\left(\mathrm{R}=0.324^{\mathrm{a}}\right)$ for the three factors indicated that there exists a weak correlation between the activities of Omo-onile and characteristics of land market in the study area.

\section{Regression Equation:}

$$
\begin{aligned}
\text { Omo-onile Activities }(\mathrm{Y}) & =63.025 *(\text { Constant })-0.206 *(\text { Equity }) \\
& -0.627 *(\text { Accessibility })-0.428 *(\text { Finance })
\end{aligned}
$$

where:

$$
\begin{aligned}
\text { Dependent Variable }= & (\mathrm{Y})(\text { Omo-onile Activities }) \\
\text { Independent Variables }= & \left(\mathrm{X}_{1}\right) \text { Equity }(-0.206) \\
& \left(\mathrm{X}_{2}\right) \text { Accessibility }(-0.627) \\
& \left(\mathrm{X}_{3}\right) \text { Finance }(-0.428)
\end{aligned}
$$

The coefficients of multiple determinations 0.105 mean that the predictors explained $10.5 \%$ variation in Activities of Omo-onile $(y)$ in the study area. Therefore, it can be deduced that the activities of Omo-onile only explain $10.5 \%$ of the land market characteristics. This is an indication that the activities of Omo-onile do not have a substantial effect on the interplay of the land market characteristics. This may be the resultant effect of the Lagos State Property Protection Law

\begin{tabular}{|c|c|c|c|c|c|c|c|c|}
\hline \multirow{2}{*}{ Model } & \multirow{2}{*}{$\mathbf{R}$} & \multirow{2}{*}{$\mathbf{R}^{2}$} & \multirow{2}{*}{$\begin{array}{l}\text { Adjusted } \\
\qquad \mathbf{R}^{2}\end{array}$} & \multirow{2}{*}{$\begin{array}{l}\text { Std. Error of the } \\
\text { Estimate }\end{array}$} & \multicolumn{4}{|c|}{ Change Statistics } \\
\hline & & & & & $\mathbf{F}$ & df1 & df2 & Sig. \\
\hline 1 & $0.324^{\mathrm{a}}$ & 0.105 & 0.088 & 2.39889 & 6.365 & 3 & 163 & 0.000 \\
\hline
\end{tabular}
promulgated in 2016 to curb the excesses of Omo-onile (Appendix $1 \mathrm{~V}$ ) and it could also be as a result of the level of importance attached to landholding by man. This addressed the recommendation made by some researchers in their

\begin{tabular}{|c|c|c|c|c|c|c|}
\hline & \multirow{2}{*}{ Model } & \multicolumn{2}{|c|}{$\begin{array}{l}\text { Unstandardized } \\
\text { Coefficients }\end{array}$} & \multirow{2}{*}{$\begin{array}{c}\begin{array}{c}\text { Standardized } \\
\text { Coefficients }\end{array} \\
\text { Beta }\end{array}$} & \multirow{2}{*}{$\mathrm{T}$} & \multirow{2}{*}{ Sig. } \\
\hline & & B & Std. Error & & & \\
\hline & (Constant) & 63.025 & 0.195 & & 322.473 & 0.000 \\
\hline \multirow{3}{*}{1} & REGR factor score 1 for analysis 2 & -0.206 & 0.292 & -0.053 & -0.706 & 0.481 \\
\hline & REGR factor score 2 for analysis 2 & -0.627 & 0.180 & -0.258 & -3.484 & 0.001 \\
\hline & REGR factor score 3 for analysis 2 & -0.428 & 0.187 & -0.172 & -2.281 & 0.024 \\
\hline
\end{tabular}
study (Oloyede, Ajibola, \& Oni, 2007).

Table 7. Model summary.

Source: Author's Field Survey (2018).

Table 8. Coefficient.

Source: Author's Field Survey (2019). 


\section{Conclusion}

Findings from the study revealed that the prominent characteristics of the land market in the study area are easy transaction in market, improved environmental management, easy accessibility to market, good condition by lenders, efficient land use management, Certainty of land ownership, Land regulation and access to experts. Whereas, the remaining land market characteristics exist but are not prominent in the study area. However, further analysis was carried out using factor analysis. The factor analysis was employed to reduce the 23 identified land market characteristics to specific harmonious component called factors and interpreted as such.

The findings revealed that Equity factor is an important categorization of land market characteristics in the study area as it accounted for $12.77 \%$ among the rest of factors extracted. The next component in the order of loading among the 23 variables is Accessibility factor with $12.64 \%$ of the extracted component. The last component which is mortgage factor with a variance of $9.09 \%$ of the extracted components is an important categorization of land market characteristics. Invariably, the three factors accounted for $34.49 \%$ variation, meaning that 12 out of the 23 variables employed as indicators were loaded highly and were categorized and named accordingly. Findings also revealed that the coefficients of multiple determinations 0.105 meaning that the predictors explained $10.5 \%$ variation in Activities of Omo-onile in the study area. Therefore, it can be deduced that activities of Omo-onile only explain $10.5 \%$ of the land market characteristics. This is an indication that the Activities of Omo-onile do not have a substantial effect on the interplay of the land market. This could be as a result of Lagos State Property Protection Law promulgated in 2016 and it could also be as a result of the degree of importance attached to land by man. Therefore their activities can be curtailed or brought into extinction in the face of appropriate policies.

\section{Recommendations}

For effective and efficient operation and functioning of the land market, the following recommendations are considered necessary. There is a need to integrate the informal institution of the market into the formal institution of the market. In furtherance to the fact that large percentage of people patronize the informal land market as established in the study.

This integration should be in the form of giving room for public-private participation in government policy/programs on land matters. This will checkmate the nefarious activities of Omo-onile when they see themselves as part of the system having a sense of belonging. Hence, the need for land policy restructuring. In accordance with the market characteristics of the land market encompassing efficiency, sustainable use of investors, access to experts, presence of formal structure, easy access to the market and the likes. The study revealed that 
Ibeju-Lekki land market does not possess adequate market characteristics. Government should carve a niche for itself and encourage collaboration in developing and executing an effective and efficient land market structure. This will also guide against any form of threat such as barriers to entry among the stakeholders. Another major finding of the study is that the activities of Omo-onile have a negative correlation on the characteristics of the land market in the study area.

\section{Conflicts of Interest}

The authors declare no conflicts of interest regarding the publication of this paper.

\section{References}

Adeniyi, K. O. (2013). Identifying and Addressing Land Governance Constraints to Support Intensification and Land Market Operation: Evidence from ten African Countries. Food Policy, 48, 76-87. https://doi.org/10.1016/j.foodpol.2014.03.003

Agbabiaka, H. O. (2016). Factors Influencing Patronage of Medical Tourism in Metropolitan Lagos. Nigeria International Journal of Scientific \& Technology, 5, 32-41.

Ajayi, O. A. (1998). Property Investment Valuation and Analysis. Bashorun: Ageless Friendship Press.

Angel, S. R. W., Tanphiphant, A. S., \& Wegalin, E. D. (1983). Land for Housing the Poor. Singapore Selects Books.

Annette, H. (2002). Two States, One City? Conflict and Accommodation in Land Delivery in Kampala, Uganda. International Development Planning Review, 28, 159-180. https://doi.org/10.3828/idpr.28.2.3

Baland, A. A. (2007). Improving Land Policy for Private Sector Development in Nigeria: Lessons and Challenges Ahead. The World Bank Conference on Land Governance in Support of the MDG5, Washington DC, 9-10 March 2007, 23-28.

Calderon, J. A. (1996). Access to Urban Land for the Poor and the Real Estate Market in Metropolitan Lima Cambridge. Cambridge, MA: Lincoln Institute of Land Policy.

Calderon, J. A. (1999). Considerations on Illegal and Informal Urban Land Markets in Latin America. Cambridge, MA: Lincoln Institute of Land Policy.

Deininger, K. W., \& Byerlee, D. (2011). Rising Global Interest in Farmland: Can It Yield Sustainable and Equitable Benefits? Washington DC: The World Bank. https://doi.org/10.1596/978-0-8213-8591-3

Dowall, S. M. (1993). The Politics of Land Deals-A Comparative Analysis of Global Land Policies on Large-Scale Land Acquisition. The Land Dividend: Land and South African Society in 1993 in Comparative Perspective Conference, Cape Town, 24-27 March 1993, 11-23.

Emmanuel, N. (2008). Understanding Informal Urban Land Access Processes from a Legal Pluralist Perspective: The Case of Kampala, Uganda. Habitat International, 32, 109-120. https://doi.org/10.1016/j.habitatint.2007.08.004

Funmilayo, L. A., \& Ogunlade, B. (2015). Effect of Urban Informal Settlements and Outdoor Advertisement on the Quality of Built Environment and Urban Upgrading in Nigeria. Journal of Emerging Trends in Economics and Management Science, 6, 332-339.

Greenspan, P. S. (1994). Moral Residues. In Practical Guilt: Moral Dilemmas, Emotions, and Social Norms (110-116). Oxford: Oxford UP. 
Holden, S. T. (2013). Growing Importance of Land Tenancy and Its Implications for Efficiency and Equity in Africa. In E. Bulte, \& R. Ruben (Eds.), Development Economics between Markets and Institutions. Incentives for Growth, Food Security and Sustainable Use of the Environment (pp. 387-405). Mansholt Publication Series Vol. 4, Wageningen: Wageningen Academic Publishers.

Jayne, J., \& Keller, G. H. (2003). Towards Pro-Poor Regulatory Guidelines for Urban Upgrading. The International Workshop on Regulatory Guidelines for Urban Upgrading, Bourton-on-Dunsmore, 38.

Kironde, W. A. (2000). Land Markets and Legal Contradictions in the Pen-Urban Area of Accra Ghana: Informant Interviews and Secondary Data Investigations.

Mooya, M., \& Cloete, C. (2007). Governance Structures for Real Estate Transactions: Markets, Networks and Hierarchies in Windhoek's Urban Low-Income Settlements. Acta Structilia, 29, 46-73.

North, D. C. (2009). Institutions, Institutional Change and Economic Performance. New York: Cambridge University Press.

Nwaka, E. (2005). Informal Land Access Processes in Akwa-Lbom, Nigeria. A Legal Pluralist Perspective. Unpublished $\mathrm{PhD}$ Thesis, Birmingham: School on Public Policy, University of Birmingham.

Oladokun, T. T. (2017). Creating an Effective Land Market in an Emerging Economy: Issues, Opportunities and Challenges. Unpublished Paper.

Oloyede, S. A., Ajibola, M. O., \& Oni, A. O. (2007). Informal Land Delivery System in Lagos Sate Nigeria. Journal of Land Use and Development Studies, 3, 139-145.

Oloyede, S. A., Osmond, I. E., \& Ayedun, C. A. (2011). Informal Land Market: Alternative Approach to Mass Residential Housing Provision in South Western Nigeria. Journal of Geography and Regional Planning, 4, 598-603.

Rakodi, C. (2006). State-Society Relations in Land Delivery Processes in Five African Cities. http://www.Researchreader.com

Rakodi, L., \& Leduka, C. (2003). Informal Land Delivery Process and Access to Land for the Poor in Six African Cities, towards Conceptual Framework. Birmingham: International Development Department, School of Public Policy.

Siastad, E. (2003). Trends in the Emergence of Agricultural Land Markets in Sub-Saharan Africa. Journal of Forum Development Study, 30, 5-28. https://doi.org/10.1080/08039410.2003.9666228 